\title{
Senhores sem escravos: a propósito das ações de escravidão no Brasil Imperial
}

Masters without

Slaves: reenslavement Lawsuits at the Brazilian Empire

\section{Keila Grinberg}

Professora do Departamento de História da Universidade Federal do Estado do Rio de Janeiro

\section{Resumo}

0 texto pretende contribuir para a exploração das práticas de re-escravização na região do Vale do Paraíba do século XIX, suas possibilidades efetivas e os significados a este processo atribuidos pelos diversos agentes sociais envolvidos. A partir da análise de ações de escravidão, processos em que o senhor acusa um suposto escravo de pretender ser livre, argumento que os senhores envolvidos em tais práticas eram senhores de poucas posses; em um contexto de alta do preço dos cativos, o recurso à Justiça era, provavelmente, a única maneira de tentarem reaver as propriedades que consideravam suas.

\begin{abstract}
The aim of the article is to understand reenslavement practices in the 19th century area of the river Paraiba valley (Vale do Paraiba), whether they were really effetctive and what they meant for those who were involved. From the analysis of enslavement law suits, in which masters accused would-be slaves of pretending to be free, it seems to me that these masters had few assets in a moment when slaves prices were high. Therefore, enslavement law suits were the only means these masters had to try to get back what they considered to be their properties.
\end{abstract}

\section{Palavras-chave}

escravos, forros, homens livres pobres, judiciário

\section{Keywords}

slaves, freedpeople, poor free people, judicial system 
Ver, entre outros, as várias análises a respeito na coletânea Direitos e Justiças no Brasil: ensaios de história social, organizada por Silvia Lara e Joseli Mendonça. Campinas: Editora da Unicamp, 2006.

2

Ver, respectivamente, GRINBERG, Keila. O fiador dos brasileiros: escravidão, cidadania e direito civil no tempo de Antonio Pereira Rebouças. Rio de Janeiro: Civilização Brasileira, 2002, principalmente parte 3 e GRINBERG, Keila. Liberata: a lei da ambiguidade: as ações de liberdade da Corte de Apelação do Rio de Janeiro no sécuIo XIX. Rio de Janeiro: Relume Dumará, 1994; SCOTT, Rebecca. A Emancipação Escrava em Cuba: a transição para o trabalho livre, 1860 1899. Rio de Janeiro: Paz e Terra; Campinas: Editora da Unicamp, 1991; HOWINGTON, Arthur. What Sayeth the Law: The Treatment of Slaves and Free Blacks in State and Local Courts of Tennessee. New York: Garland, 1986.

3

Para as ações de liberdade e sua vigência mesmo antes do predomínio de uma dinâmica crioula na relação entre senhores e escravos, ver, entre outros, CHALHOUB, Sidney. Visões da liberdade. Uma história das últimas décadas da escravidão na corte. São Paulo: Companhia das Letras, 1990. GRINBERG, Keila. Op.Cit.; AZEVEDO,

Elciene. Orfeu de carapinha. Campinas: Unicamp, 1999; PENA, Eduardo Spiller. Pajens da casa imperial. Campinas: Unicamp, 2001; MENDONÇA, Joseli. Entre a mão e os anéis. Campinas: Unicamp, 1999. Para a relação entre a conjuntura aberta pela abolição do tráfico internacional e a intensificação das ações de liberdade, bem como para o próprio conceito de deslegitimação da escravidão, ver: MATTOS, Hebe. Das cores do silêncio - significados da liberdade no Sudeste escravista. Brasil. Século XIX. Rio de Janeiro: Arquivo Nacional, 1995.

\section{4}

MATTOS, Hebe. Op.Cit. MATTOS, Hebe. Laços de família e direitos no fim da escravidão. In: História da vida privada no Brasil II; Império: a corte e a modernidade nacional. São Paulo: Cia das Letras, 1997; CHALHOUB, Sidney. Op.Cit. GUEDES, Roberto. Pardos: trabalho, familia, aliança e mobilidade social em Porto Feliz, São Paulo, c. 1798 - c. 1850. 2005. (Tese de Doutorado). Programa de Pós-graduação em História Social, Universidade Federal do Rio de Janeiro, 2005.

5

MENDONÇA, Joseli. Op.Cit.

6

Arbitramento (preço de escravos), caixa 02. $1^{\circ}$ ofício de notas, grupo civel, Arquivo Cartorário do Poder Judiciário. 1874. Centro de Documentação Histórica, Vassouras.
"É irrisório que a testemunha que se diz professor de filosofia queira distinguir modos de vida próprios de livres, e modos de vida próprios de escravos. Declaro que é tão metafísico que não compreendo". Curador de uma suposta escrava, ao ironizar o comentário da testemunha que diz saber que uma pessoa é escrava por seu modo de vida." Rio de Janeiro, 1874.

Muitos historiadores, nos últimos anos, estudaram as formas pelas quais, durante a vigência da escravidão nas Américas, o direito simultaneamente contribuiu para perpetuar o poder de proprietários sobre seus escravos e para que escravos e libertos conseguissem desafiar o poder de seus senhores. ${ }^{1}$ No Brasil, em Cuba e no Sul dos Estados Unidos, para mencionar apenas os casos mais conhecidos, a pesquisa arquivistica descortinou evidências de padrões complexos de demandas judiciais por escravos e libertos, que encontraram diferentes graus de sucesso. ${ }^{2}$ No caso especifico do Brasil, o direito pode ser caracterizado, ao mesmo tempo, como elemento fundamental para garantir a manutenção da escravidão e como veículo para garantia da cidadania. É o que mostram os estudos sobre alforria e direito no século XIX de autores como Sidney Chalhoub, Hebe Mattos, Eduardo Spiller Pena, Elciene Azevedo e Joseli Mendonça, que vêm evidenciando a importância das ações judiciais no processo de deslegitimação da escravidão na segunda metade do século XIX no Brasil, não apenas como recurso para pressionar pela obtenção da alforria por alguns grupos específicos de escravos - principalmente aqueles localizados em áreas urbanas ou em zonas rurais próximas aos locais de atuação de grupos abolicionistas - mas também no processo mais amplo de discussão da emancipação geral, pelo menos a partir da década de $1860 .^{3}$

0 objetivo deste texto é contribuir para a exploração das práticas de re-escravização no Brasil do século XIX, refletindo sobre suas possibilidades efetivas e os significados a este processo atribuidos pelos diversos agentes sociais envolvidos. Trata-se, neste sentido, de aproximar a lente da análise para os indivíduos que vivenciaram este processo, refletindo sobre os riscos que enfrentaram em suas trajetórias, sobre a fragilidade da condição de liberto e, principalmente, sobre a instabilidade de suas vidas, marcadas pelo temor em verem revertidas suas conquistas. ${ }^{4}$

Vejamos, por exemplo, a atitude da parda Constança, que em 1874 procurou a Justiça para propor o arbitramento de sua liberdade. Constança já havia pagado a Leopoldino, seu senhor, a quantia de 300 mil réis, já havia oferecido a ele mais 200 em juizo, mas Leopoldino só aceitava 1 conto e 100 mil réis, valor pelo qual foi avaliada, dois anos depois de ter sido avaliada em 500 mil réis. Por isso Constança pedia um novo arbitramento de seu valor. Até aí, nada de mais. São inúmeros os casos nos quais senhor e escravo divergem sobre a quantia a ser paga pela obtenção da liberdade. ${ }^{5}$ 0 interessante é que ela demonstrava suspeitar da pessoa que a avaliaria, e pede sua substituição, por estar "determinada em não deixar dúvidas futuras sobre sua condição de livre, se a conseguir"6. Se Constança estava preocupada em não deixar dúvidas sobre sua nova condição, é porque ela sabia que corria o risco.

E o risco existia mesmo. Mais ou menos na mesma época, no início da década de 1870, a parda Brasília foi re-escravizada na Corte por Clélia Leopoldina de Oliveira, após ter vivido vários anos como liberta. Brasília veio da Bahia - no processo, não é mencionado quando isto aconteceu - no paquete inglês "Biela", onde não eram permitidos escravos, em companhia de sua suposta senhora. Ao chegar à Corte, passou a viver como liberta, 
7

Ação de Escravidão. Caixa 3688, Número 14318. Corte de Apelação. Arquivo Nacional, RJ.

8

Biografia de Antonio Pereira Rebouças. Coleção Antonio Pereira Rebouças, Seção Manuscritos, Biblioteca Nacional, I-3,24,61. Relatei este caso em GRINBERG, Keila. 0 fiador dos brasileiros: escravidão, cidadania e direito civil no tempo de Antonio Pereira Rebouças. Rio de Janeiro: Civilização Brasileira, 2002. Cap.03.

Sobre a revolta de 1851, ver os textos de PALACIOS, Guillermo, "Revoltas camponesas no Brasil escravista: a 'Guerra dos Maribondos' (Pernambuco, 1851-1852)", DANTAS, Monica Duarte, "Cronica de um debate", MATTOS, Hebe Maria, "Identidade camponesa, racialização e cidadania no Brasil monárquico: o caso da 'Guerra dos Marimbondos' em Pernambuco a partir da leitura de Guillermo Palacios" e OLIVEIRA, Maria Luiza Ferreira de, "Sobreviver à pressão escapando ao controle: embates em torno da "lei do cativeiro" (a Guerra dos Marimbondos em Pernambuco, 18511852)", todos publicados na Revista Almanack Brasiliense, número 3, maio de 2006. Sobre os casos de re-escravização na fronteira do Brasil com os paises vizinhos, ver PETIZ, Silmei de Sant'Ana. Buscando a liberdade: as fugas de escravos da província de São Pedro para o além-fronteira (1815-1851). Passo Fundo: Universidade de Passo Fundo, 2006. GRINBERG, Keila. Escravidão, alforria e direito no Brasil oitocentista: reflexões sobre a lei de 1831 e o 'princípio da liberdade' na fronteira sul do Império brasileiro. In: CARVALHO, José Murilo de (org.). Nação e Cidadania no Oitocentos. Rio de Janeiro: Civilização Brasileira, 2007.

\section{0}

CHALHOUB, Sidney. "Illegal Enslavement and the Precariousness of Freedom in NineteenthCentury Brazil", inédito; HOLLOWAY, Thomas H. Polícia no Rio de Janeiro: repressão e resistência numa cidade do século XIX. Rio de Janeiro: Fundação Getúlio Vargas, 1997. SOARES, Carlos Eugênio Libano. A capoeira escrava e outras tradições rebeldes no Rio de Janeiro (18081850). Campinas: Editora da UNICAMP, 2001. pagando, inclusive, os aluguéis das casas onde morou. Ao ser perguntada por que veio como livre, respondeu que "veio como livre porque nunca se considerou escrava". Mas sabia que poderia sê-lo: provavelmente percebendo as intenções de D. Clélia, "pedira e obtivera pelo Juiz Municipal da 2a Vara ser manutenida na posse de sua liberdade, tendo a sentença passado em julgamento"7. Muitos aspectos podem ser discutidos neste caso. Um deles é se Brasília foi registrada como livre apenas para poder embarcar em navio inglês. Outro é se o fato de ter pisado no navio inglês já não seria argumento suficiente para mantê-la em estado de liberdade - argumento que não chegou a ser levantado por seus curadores. Por fim, caberia a pergunta se Brasilia não estaria se aproveitando das circunstâncias para conseguir sua carta de alforria. Mas as circunstâncias, neste caso, importam menos do que o resultado da ação: Brasília, provavelmente nascida escrava mas tida como livre por seus vizinhos e pelo inspetor do quarteirão onde vivia, foi re-escravizada.

Por incrivel que pareça, problema semelhante enfrentou o então herói da Independência Antonio Pereira Rebouças, que, mesmo nunca tendo sido escravo, passou por diversos infortúnios ao viajar da Bahia para a Corte na década de 1820. Ao chegar em Porto Seguro, foi embaraçado de seguir viagem, mas "valendo-Ihe o conhecimento que já ai tinha de seu nome e a persuasão de sua identidade pelo conhecimento pessoal que manifestou ter das mais notáveis ocorrências patrióticas e profissionalmente da legislação em matéria forense" conseguiu prosseguir, não sem antes dar uma ajudinha ao Juiz ordinário local. ${ }^{8}$ Rebouças contou o episódio em sua autobiografia e, embora não especifique os motivos que levaram ao incidente, claro está que ele poderia ser confundido com outra pessoa de status e condição inferior.

Estes exemplos constituem apenas uma faceta das várias práticas de re-escravização existentes no Império Brasileiro, entre as quais podemos citar o roubo de pessoas, freqüente na região de fronteira entre o Brasil e seus vizinhos republicanos que já haviam abolido a escravidão em seus territórios, e os temores e boatos presentes em alguns movimentos populares, como é o caso da revolta dos marimbondos, em Pernambuco, originada pela promulgação do Regulamento do Registro de Nascimentos e Óbitos em 1851, sintomaticamente denominada, na época, de "lei do cativeiro"9. Isto sem falar nos casos de re-escravização que ocorriam cotidianamente, na Corte principalmente, mas também em outras cidades, em que qualquer pessoa que pudesse parecer escravo tinha, contra si, a presunção da escravidão. Assim, como demonstram aqueles que estudaram as atitudes da polícia no século XIX, cabia àqueles que tinham sido detidos pela polícia provar a própria liberdade, sob pena de serem reduzidos à escravidão. ${ }^{10}$

Entre estes casos, chama a atenção um tipo específico de ação judicial,ainda não suficientemente explorada pela historiografia a respeito, e sobre a qual não há, ainda, evidências de existência em outras paragens das Américas: trata-se das ações de escravidão. Ao contrário das ações de liberdade - nas quais um ou um conjunto de supostos escravos inicia um processo judicial contra seu suposto senhor, argumentando seu direito à libertação - e das ações de manutenção de liberdade - em que um liberto procura a Justiça para garantir seu status, quase sempre por estar ameaçado de re-escravização, nas ações de escravidão quem inicia o processo é o senhor. Nelas, ele processa um outro cidadão, alegando que a pessoa em questão se passa indevidamente por livre, sem sê-lo. Em outras palavras, o 
11

Cabe esclarecer, aqui, que as referidas ações situam-se exclusivamente no âmbito dos tribunais de segunda instância, a saber, a Corte de Apelação do Rio de Janeiro. Embora sejam encontrados processos relativos a todo o Brasil e ao século XIX como um todo, a maioria concentra-se geograficamente, nas regiões da Corte, das províncias do Rio de Janeiro, São Paulo, Minas Gerais, Paraná e Rio Grande do Sul. Da mesma forma, embora haja ações posteriores a 1870 , a maioria concentra-se entre 1830 e 1869. Para mais informações sobre as fontes, ver GRINBERG, Keila. Liberata: a lei da ambiguidade: as ações de liberdade da Corte de Apelação do Rio de Janeiro no século XIX. Rio de Janeiro: Relume Dumará, 1994.
12

GRINBERG, Keila. "Re-escravização, direitos e justiças no Brasil do século XIX". In: LARA, Silvia e MENDONÇA, Joseli (org.). Direitos e Justiças no Brasil: ensaios de história social. Campinas: Editora da Unicamp, 2006. objeto da ação de escravidão é justamente questionar a condição jurídica do réu, ao argumentar que ele seria não apenas escravo, como também propriedade do autor da ação.

Encontrei as ações de escravidão ao realizar levantamento das ações de liberdade existentes na Corte de Apelação do Rio de Janeiro, quando classifiquei-as, entre outros quesitos, de acordo com os argumentos e os motivos que seus autores - supostos escravos - apresentavam para obter suas liberdades. ${ }^{11} \mathrm{Na}$ ocasião, interessada em outras questões, limitei-me a classificar as ações de escravidão em conjunto com as ações de manutenção de liberdade, sem, contudo, analisá-las. (ver gráfico 1).

Grafico 1: Ações civeis relativas à liberdade e à reescravização do Tribunal da Relação do Rio de Janeirono século XIX

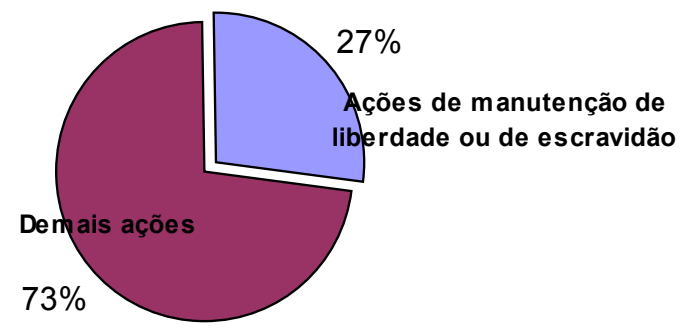

Fonte: Tribunal da Relação do Rio de Janeiro - Arquivo Nacional - RJ Total: 402 ações

Embora os procedimentos jurídicos das ações de manutenção de liberdade e de escravidão fossem diferentes, ambos podem ser aqui definidos como sendo processos de re-escravização, pois suscitaram debates distintos daqueles realizados nas ações de liberdade: além da verificação da veracidade das versões contadas por ambas as partes, como em qualquer processo, nestes casos tratava-se de discutir em que medida era possivel voltar atrás em uma doação de liberdade, principalmente quando o indivíduo em questão já foi libertado há muito tempo. Ao invés da passagem do estado de escravidão para o estado de liberdade, que ocorria nas ações de liberdade, os processos de re-escravização tratavam de discutir as possibilidades e a própria legitimidade da passagem da liberdade para a escravidão.

Em texto anterior, para entender a ocorrência destas ações, analisei as possibilidades juridicas existentes no direito brasileiro de então, buscando as leis que tornavam possivel a existência destas ações e os instrumentos jurídicos efetivamente utilizados por advogados para argumentar a favor de seus clientes, fossem eles senhores ou escravos. Ao mesmo tempo, procurei concentrar-me nas soluções encontradas pelos agentes da justiça ao longo do século XIX para lidar com situações como aquelas, avaliando a eficácia destes argumentos junto aos juizes e, principalmente, as sentenças que estes proferiram, para analisar sua legitimidade em um universo no qual a legitimidade da própria escravidão começava a estar em jogo. ${ }^{12} \mathrm{Um}$ dos argumentos que caiu em desuso ao longo do século XIX, como já o havia demonstrado Perdigão Malheiro em A Escravidão no Brasil (1866), foi o da revogação da alforria por ingratidão, conforme rezava o título 63 do livro 4 das Ordenações Filipinas.

Na ocasião, cheguei a duas conclusões: a primeira, analisando o número de ações de escravidão e de manutenção de liberdade que chegaram à Corte de Apelação do Rio de Janeiro no século XIX e seus 
13

Como as sentenças favoráveis aos senhores eram automaticamente enviadas à Corte de Apelação, estes resultados também podem indicar uma progressiva dificuldade na obtenção de sentenças favoráveis nos tribunais de primeira instância. Esta afirmação ainda carece de pesquisa especifica sobre os tribunais de primeira instância; aliás, ainda está por ser feita a importante comparação entre o desempenho dos tribunais de primeira e segunda instância nas decisões relativas à liberdade de escravos. resultados (gráficos 2 e 3), é a constatação de que mais escravos iniciaram ações de manutenção de liberdade na justiça do que o inverso; a segunda dizia respeito à consciência dos escravos de suas chances de vitória nestes processos, grandes principalmente em tribunais de segunda instância. ${ }^{13}$

Grafico 2: Resultados das Ações de Re-escravisação no século XIX

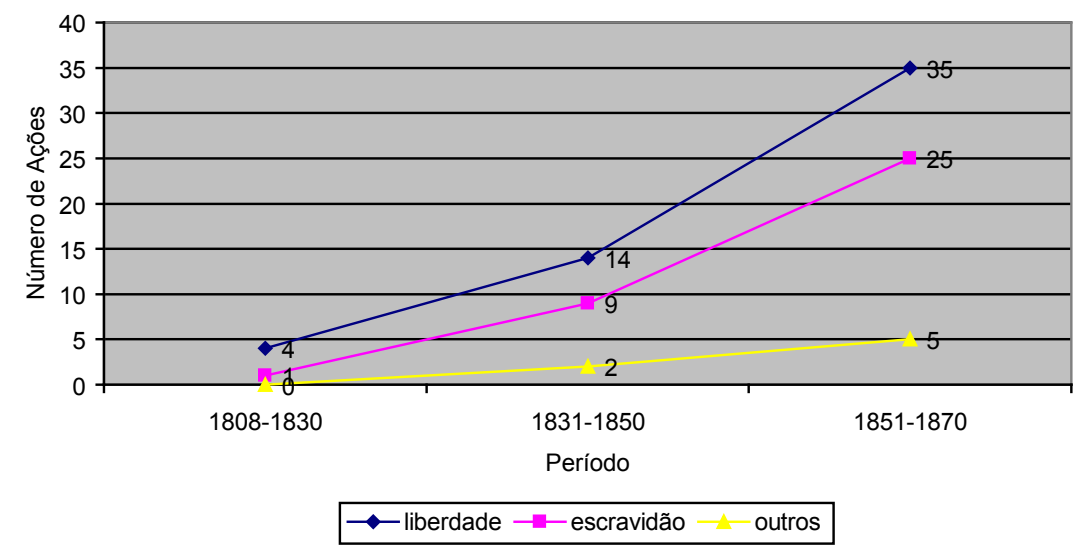

Grafico 3: Ocorrência de Ações de Escravidão e de manutenção de Liberdade no século XIX

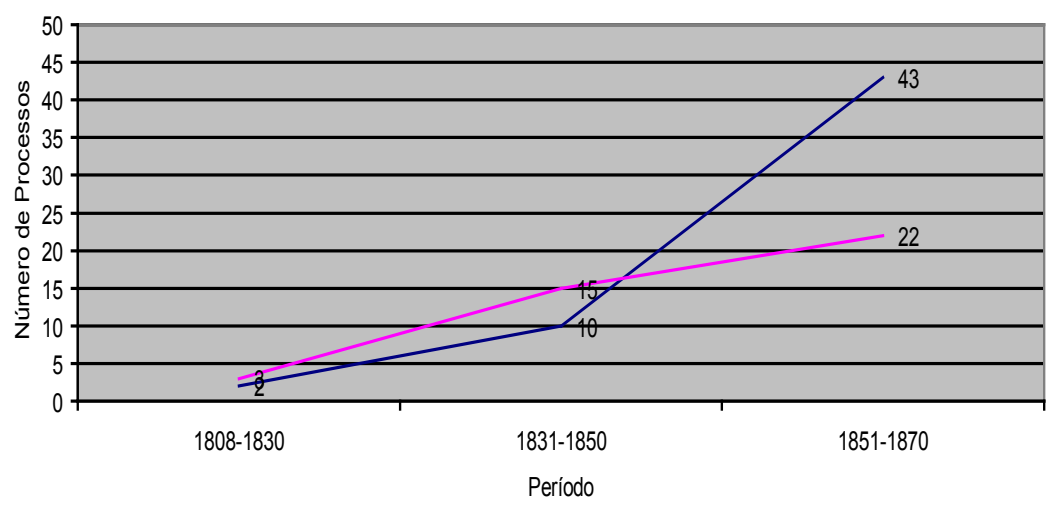

ações de manutenção de liberdade —ações de escravidão

Reconhecendo que estes dados forneciam muitas informações acerca do estado das relações entre senhores e escravos na segunda metade do século XIX, conclui que eles informavam ainda mais acerca da legitimidade jurídica das ações cíveis de escravidão e manutenção da liberdade: eles demonstram que, paralelamente ao que então acontecia nas ruas, dentro dos tribunais - ao menos nos tribunais de segunda instância -, a legitimidade da escravidão também estava com os dias contados.

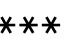

Sem questionar a validade deste argumento em termos gerais, hoje pareceme que os dados encontrados, analisados principalmente do ponto de vista quantitativo, foram olhados com excessivo otimismo. Em primeiro lugar, porque não se tratava, evidentemente, dos escravos de maneira geral: para fazer apenas uma clivagem genérica, basta confirmar o que tantos já disseram a respeito das maiores possibilidades dos crioulos chegarem à Justiça do que os africanos. ${ }^{14}$ No caso do médio Vale do Paraiba, o maior
14 silêncio - significados da liberdade no Sudeste escravista. Brasil. Século XIX. Rio de Janeiro: Arquivo Nacional, 1995. 
poder dos escravos crioulos em transformar a negociação privada em processo judicial fica evidenciada através da comparação entre os dados obtidos no levantamento das ações de liberdade em geral e os dados coletados nos inventários arquivados no Centro de Documentação Histórica de Vassouras, todos referentes ao mesmo período:

Grafico 4: Comparação entre Origens dos Escravos - Ações de Liberdade e Inventários séc XIX - Vale do Paraiba Fluminense

\section{5}

Estes últimos dados foram coletados no âmbito da pesquisa "Escravidão, Liberdade e Direito em Vassouras no século XIX - Redes de sociabilidade e ampliação de espaços de direitos da população escrava (c. 1840 - 1888)", coordenada po Ricardo Salles, no âmbito de Primeiros Projetos - FAPERJ/CNPq, 2003-2006, do qual este texto é resultado.

\section{6}

LARA, Silvia. "Introdução", Ordenações Filipinas - livro 5. São Paulo: Companhia das Letras, 1999; RUSSELL-WOOD, A.J.R. "Acts of Grace: Portuguese Monarchs and their Subjects of African Descent in Eighteenth Century Brazil". Journal of Latin American Studies, vol. 32, p. 307-332, maio de 2000. WEHLING, Arno \&t WEHLING, Maria José. Direito e Justiça no Brasil Colonial: o Tribunal da Relação do Rio de Janeiro (1751-1808). Rio de Janeiro: Renovar, 2004; HESPANHA, Antonio Manuel. "Da 'iustitia' à 'disciplina'. Textos, poder e política penal no Antigo Regime". In: Justiça e Litigiosidade: história e prospectiva. Lisboa: Fundação Calouste Gulbenkian, 1993.

\section{7}

Este título da ordenação filipina foi citado em 12 outras ações, além desta; mas a referência à lei, nestes casos, não correspondia diretamente a seu conteúdo. Ver, a respeito, GRINBERG, Keila. "Re-escravização, direitos e justiças no Brasil do século XIX". In: LARA, Silvia e MENDONÇA, Joseli (org.). Direitos e Justiças no Brasil: ensaios de história social. Campinas: Editora da Unicamp, 2006.

18

Ação de Escravidão, caixa 3683, número 81828, Corte de Apelação, Arquivo Nacional - RJ.

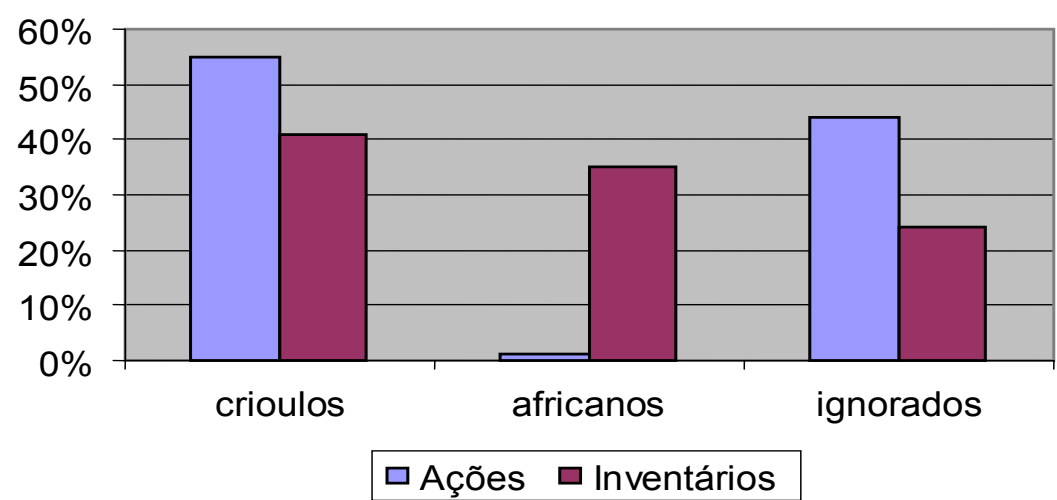

Fonte: Ações de Liberdade da Corte de Apelação do Rio de Janeiro - Arquivo Nacional e Inventários relativos a proprietários de escravos depositados no Centro de Documentação Histórica, Vassouras 15

Embora haja um grande número de escravos de origem ignorada - o que pode ser omissão da documentação, mas pode muito bem tratar-se de esperteza dos senhores, que omitiam dados relativos a africanos chegados no Brasil depois de 1831, para escamotear a escravização ilegal -, como demonstrado no gráfico acima, o número de africanos que lograva alcançar a Justiça era, de fato, muito pequeno. Esta constatação é corroborada pela leitura própria das ações de escravidão, nas quais figuram, dentre todos os processos, apenas três africanos.

Em segundo lugar, se é maior o número de ações que têm como resultado a liberdade do que o inverso, o número de processos que, ao final, reiteravam a escravidão de seus atores ainda era grande. 0 mesmo vale para a ocorrência das ações de escravidão - o que talvez seja o dado mais interessante. Embora a quantidade de ações de manutenção de liberdade fosse maior - crescentemente maior, ao longo do século XIX - do que a ocorrência de ações de escravidão (gráfico 3), é impossivel deixar de perceber o ligeiro crescimento no número destes processos no mesmo periodo.

Por fim, o próprio argumento do recurso à Justiça: como já o demonstraram Silvia Lara e A.J.R. Russell-Wood, entre outros, buscar a mediação da justiça - e do monarca - para resolver contendas privadas era prática comum desde o tempo do Antigo Regime português. ${ }^{16}$ Interessante que, nos processos de que dispomos, os argumentos encontrados já eram marcadamente modernos. De todos os processos encontrados, apenas um, ocorrido em 1826, em Salvador, utiliza o argumento da ingratidão da liberta para obter a revogação da alforria, como previa o título 63 do livro 4 das Ordenações Filipinas. ${ }^{17}$ Mesmo assim, era uma situação em que o argumento da ingratidão servia, na verdade, de cortina para um triângulo amoroso entre o senhor, a escrava (com quem ele tinha dois filhos) e a senhora. Fica claro, lendo os argumentos de ambas as partes, que ele libertou a cativa a pedido de sua mulher e depois, com ciúmes, se arrependeu. ${ }^{18}$ 


\section{9}

MALHEIRO, Agostinho Marques Perdigão. A escravidão no Brasil - ensaio histórico, jurídico, social. Petrópolis: Vozes/INL, 1976 (1866), vol. 1, p. 167.

\section{0}

Para a discussão sobre o status dos libertos na Constituinte de 1823 e na Constituição de 1824, ver RODRIGUES, José Honório. A Assembléia Constituinte de 1823. Petrópolis: Vozes, 1974; RODRIGUES, Jaime. 0 infame comércio: propostas e experiências no final do tráfico de africanos para o Brasil (1800-1850). Campinas: Unicamp, 2000 e "Liberdade, humanidade e propriedade: os escravos e a Assembléia Constituinte de 1823". Revista do Instituto de Estudos Brasileiros da USP, N.39, p.159-167, 1995; MARQUESE, Rafael e BERBEL, Márcia. "La esclavitud en las experiencias constitucionales ibéricas, 1810-1824." In: FRASQUET, Ivana (org.) Bastillas, cetros y blasones. La Independencia en Iberoamérica. Madrid: Fundación MapfreInstituto de Cultura, 2006, p.347-374. GRINBERG, Keila. 0 fiador dos brasileiros: escravidão, cidadania e direito civil no tempo de Antonio Pereira Rebouças. Rio de Janeiro: Civilização Brasileira, 2002. cap.03.

21

FLORENTINO, Manolo. "Sobre minas, crioulos e a liberdade costumeira no Rio de Janeiro, 17891871". In: Tráfico, cativeiro e liberdade - Rio de Janeiro, séculos XVII-XIX. Rio de Janeiro: Civilização Brasileira, 2005 e SALLES, Ricardo. E o escravo era o Vale. Vassouras - século XIX. Senhores e cativos no coração do Império. Rio de Janeiro: Civilização Brasileira, no prelo.

\section{2}

Manolo Florentino demonstra que o valor de um escravo homem, entre 15 e 40 anos de idade, dobrou entre o final do século XVIII e os anos 1820; entre esta data e a década de 1830, o valor dobrou novamente. Finalmente, entre o preço deste escravo em 1840 e na década seguinte, o valor chegou a triplicar, continuando ainda a subir na década de 1860. FLORENTINO, Manolo. Op.Cit.
Os outros argumentos encontrados, no entanto, são diferentes. Todos envolvem disputas sobre a validade de documentos como cartas de alforria, assentos de batismo, testamentos. Questiona-se se determinado fato citado por uma das partes aconteceu ou não, questiona-se se tal documento é verdadeiro ou não. Isto não significa, evidentemente, que a pretensão de escravização ilegal estivesse diminuindo com o tempo: muito pelo contrário. Mas, ao que parece, a lógica da argumentação jurídica, tanto em termos formais - citação da legislação - quanto reais - conteúdo da ação -, estava efetivamente em mudança ao longo do século XIX. Coisa, aliás, que já havia notado Perdigão Malheiro em 1866, ao estabelecer que, na prática, a revogação da alforria por ingratidão já não existia - o que significava que a ordenação filipina correspondente, embora ainda em vigor, já não era mais legítima. ${ }^{19}$

Para Perdigão Malheiro e outros jurisconsultos da época, apenas os escravos que ainda estavam cumprindo condição poderiam ter suas alforrias revogadas por ingratidão já que, por não estarem ainda no pleno gozo dos seus direitos civis, não podiam ser considerados cidadãos. Mas, se o individuo já estivesse em posse plena de sua liberdade, não podia mais ser reduzido à escravidão por motivo de ingratidão, porque já seria um cidadão e cidadãos, de acordo com a Constituição de 1824, não podem perder seus direitos de cidadania (à exceção de 3 razões, não contempladas nesta questão). Curioso que nem Perdigão Malheiro nem seus colegas jurisconsultos discutiram as questões jurídicas relativas às possibilidades de reescravização de africanos, ou seja, daqueles libertos que, mesmo estando "em plena posse de sua liberdade", não eram considerados cidadãos porque não tinham nascido no Brasil. 20

Cabe esclarecer, no entanto, se o movimento da argumentação jurídica corresponde a alguma perda de legitimidade da proposição de ações de escravidão ao longo do século XIX. Não é o que parece. Conforme demonstrado no gráfico 3, embora o número de ações de manutenção de liberdade cresça num ritmo mais rápido do que as ações de escravidão, principalmente no período posterior a 1850, também há um crescimento no número de propostas destas ações. Neste sentido, a questão que se coloca é: mesmo que os casos de re-escravização tenham ocorrido ao longo de todo o período de vigência da escravidão e possivelmente tenham aumentado no final do século XIX, não seriam as ações de escravidão (ou, pelo menos, seu uso recorrente) um produto do Oitocentos?

Embora não se disponha de dados passiveis de comparação para o periodo anterior a 1808, a situação da escravidão no século XIX leva a crer que estamos diante de um quadro específico. Vejamos. De acordo com os dados levantados por Manolo Florentino, Mary Karasch e Ricardo Salles, entre outros, o século XIX, principalmente na região da Corte e do Vale do Paraiba, conheceu uma retração no número relativo de alforrias em relação ao século XVIII. Alforriava-se muito no século XVIII, muito pouco no século XIX, pelo menos até a entrada em vigência da Lei de $1871 .{ }^{21}$ A razão principal? A alta dos preços dos escravos, decorrente das pressões inglesas, da Lei de 1831 e, posteriormente, da Lei Euzébio de Queiróz, de 1850.22

Assim, com a alta sucessiva do preço dos escravos, era mais difícil, para aqueles cativos que vinham economizando para comprar suas liberdades, que alcançassem seus objetivos. Isto fazia com que a negociação entre senhores e escravos, sempre existente nos processos de obtenção de liberdade, muitas vezes, gerasse conflitos - que tanto podia provocar 
23

A autora cita casos de pessoas que já haviam conseguido suas alforrias em regiões como Minas Gerais e Goiás foram escravizadas e vendidas para o sul, inclusive com a participação de autoridades municipais. FREITAS, Judy Bieber.

"Slavery and social life: in the attempts to reduce free people to slavery in the Sertão Mineiro, Brazil, 1850-1871". Journal of Latin American Studies, vol.26, n.3, 1994, p.597-619; para possibilidades de re-escravização de indígenas, ver MONTEIRO, John Manuel. Negros da terra. São Paulo: Companhia das Letras, 1995.

24

Ação de escravidão, caixa 3690, número 9, 1812. Corte de Apelação. Arquivo Nacional - RJ.

\section{5}

Ação de escravidão, caixa 3695, número 7, 1836. Corte de Apelação. Arquivo Nacional - RJ. atitudes como fugas e crimes quanto podia gerar processos na Justiça. Afinal, tanto as ações de manutenção de liberdade quanto as ações de escravidão são a tentativa de solucionar, no âmbito público, um longo processo de negociações ocorridas na esfera privada.

Todas estas razões me levam a crer que acabei deixando de considerar, na análise anterior, o aspecto que hoje me parece crucial para entender as práticas de re-escravização no Brasil oitocentista: as próprias razões da existência das ações de escravidão e de sua permanência ao longo do século XIX, principalmente nas regiões vizinhas à Corte, no Vale do Paraíba e em Minas Gerais. Afinal, por que um senhor sairia de sua casa para ir à Justiça reclamar seu suposto escravo? Não haveria outros meios, mais rápidos e eficazes, para forçá-lo a voltar ao lugar de onde não deveria ter saído? Por que anos e anos de debate, por meio de curadores e advogados, em processos que transitavam em diversos tribunais, sem a certeza de um resultado favorável? Ou seja: para além das questões jurídicas, existentes a partir do momento que a ação é iniciada, quais eram os motivos, na relação entre senhores e escravos, que provocavam uma ação de escravidão?

A situação inversa é mais clara. Afinal, num contexto de crescente instabilidade do estado de liberdade e ameaças de re-escravização, principalmente depois do fim do tráfico atlântico - quando a demanda por escravos no Vale do Paraiba cresceu de tal maneira que muitos libertos, de diferentes regiões, se viram ameaçados, como demonstrou Judy Bieber ${ }^{23}$-, entende-se que libertos tenham procurado a Justiça para garantir suas condições e refrear tentativas de captura. Mas, os senhores? Por que fariam o mesmo?

Para aprofundar a discussão, vejamos o caso de André Luiz Quaresma, que foi a juizo tentar anular as liberdades de seus dois escravos mulatos - Felisberto de 22 anos e João de 18 - que sua mãe havia libertado "na decrépita idade de mais de oitenta anos, cega e molesta", sem seu consentimento nem aprovação. André argumentava que sua mãe não podia ter feito isto, até porque eram estes escravos que mantinham, com os seus serviços, a subsistência de ambos. Aconteceu em 1812, no Rio de Janeiro. 24 As testemunhas reafirmaram a importância dos dois escravos para a economia doméstica. Em 1836, em Magé, caso semelhante ocorreu. Miguel Marques da Silva entrou com uma ação contra Maria crioula por ela ter sido libertada por sua mãe, senhora de 90 anos, enferma e sem juizo, "seduzida por pessoas de má conduta"25. Da mesma forma, Miguel argumentou que necessitava da escrava para sua subsistência. Em ambos os casos, a sentença favoreceu os senhores, mandando que os ditos escravos voltassem ao poder de seus supostos senhores.

Como estes, várias são as ações de escravidão nas quais o autor alega serem os escravos em questão os principais, se não os únicos, bens da família. Em outras, a ação é uma maneira de tentar resolver disputas conjugais, nas quais a mulher é, formalmente, escrava de seu companheiro. Em outras, ainda, a contenda envolvia senhores que eram, eles próprios, forros. Como no caso de Anna Rosa de Vasconcelos, que em 1838 processou Antonia, de nação mina, por esta se recusar a servi-la. Antonia havia sido escrava de um certo Antonio Pinto, preto forro, também mina. Em dificuldades financeiras, Antonio havia hipotecado sua escrava Antonia a d. Anna. Como não tivesse pago sua dívida no prazo acordado, perdeu a escrava 
26

Ação de escravidão, caixa 3691, número 11, 1838. Corte de Apelação. Arquivo Nacional - RJ.

27

Ação de manutenção de liberdade, maço 225, número 2536, 1867. Corte de Apelação. Arquivo Nacional - RJ.

28

Ação de escravidão, caixa 3688, número 14318, op. cit. para ela. Mesmo assim, a nova senhora consentiu que Antonia continuasse vivendo com Antonio Pinto, trocando-a por um outro escravo, de nome João. Tempos depois, Antonio Pinto morreu, deixando Antonia forra em testamento. Foi quando Anna Rosa reclamou a posse de Antonia e de sua filhinha, nascida depois da transação, e começou toda a confusão. Antonia alegou que era forra, mas os juizes entenderam o oposto: mantida como escrava, ela foi obrigada a passar à posse de d. Anna. ${ }^{26}$

Ou como o caso - formalmente ação de manutenção de liberdade - de Joaquim Francisco Pacheco, forro mina, e Rita, também mina, ocorrido em 1867 na Corte. Rita afirma ter pago 350 mil réis de uma vez a seu antigo senhor, José Gomes de Oliveira e Silva, e depois mais 368 mil réis em prestações, sem que seu novo senhor tivesse passado documento algum referente ao dinheiro recebido. Joaquim, por sua vez, diz que nunca recebeu nada de sua escrava. A história merece um olhar mais detido: pelo que relatam as testemunhas, Rita estaria em uma casa de comissão para ser vendida por 900 mil réis. Como não quisesse ser vendida e só dispunha de cerca de 300 mil réis - o valor exato não está claro no processo -, ela teria implorado a Joaquim para que este completasse seu valor. 0 que não está claro é se ela teria ficado livre, tendo pago o que devia aos poucos, ou se teria passado a ser escrava de Joaquim, e o dinheiro que teria Ihe dado seria referente aos jornais. 0 juiz concluiu que Rita era escrava de Joaquim. ${ }^{27}$

Do conjunto destas citações, alguns exemplos dos cerca de cem casos relativos à re-escravização encontrados na Corte de Apelação do Rio de Janeiro ao longo do século XIX, fica claro que os senhores envolvidos nestas ações estão longe da caracterização genérica atribuída aos senhores de escravos, como "elite branca". Brancos, até pode ser que alguns o fossem; mas "elite" com certeza não eram.

Muito pelo contrário: o que a análise destes processos deixa entrever é que estas disputas envolvem pessoas de situação social muito próxima. São forros, ou descendentes daqueles tantos que lograram conseguir suas alforrias ao longo dos séculos XVII e XVIII. 0 que os distingue é a condição, ou melhor, a suposta condição de alguns, se livres, libertos ou escravos. Não é pouco, evidentemente. Mas trata-se de pessoas que freqüentam os mesmos lugares, têm amigos em comum, falam a mesma língua.

Este é o principal aspecto a ser ressaltado. Se as pessoas que iniciam as ações de escravidão podem ser caracterizadas como "senhores", são senhores de poucas posses. Da mesma forma, as pessoas a quem eles querem caracterizar como cativos, de fato, viviam como livres, agiam como livres, trabalhavam como livres. Impossivel, à primeira vista, distinguir estes escravos dos livres. Foi, aliás, o que disse o curador de um deles, ironizando uma testemunha, professor de filosofia, que afirmou ser a acusada escrava porque "o modo de vida da ré na Bahia prova sua escravidão": "É irrisório que a testemunha que se diz professor de filosofia queira distinguir modos de vida próprios de livres, e modos de vida próprios de escravos. Declaro que é tão metafísico que não compreendo" 28 .

Assim, no caso das ações de escravidão, principalmente naqueles casos que o próprio senhor é forro, a fronteira que o separa de seu próprio escravo parece ser muito tênue (não seria este senhor, ele também, no limite, passivel de re-escravização?). Não há, em nenhum dos casos, senhores de muitas posses envolvidos, em nenhuma época do século XIX em nenhuma região. 
29

FRANCO, Maria Sylvia de Carvalho. Homens livres na ordem escravocrata. São Paulo: Ática, 1974. CUNHA, Manuela Carneiro da. "Sobre os silêncios da lei: lei costumeira e positiva nas alforrias dos escravos no Brasil do século XIX". In: Antropologia do Brasil. Mitos, história, etnicidade. São Paulo: Brasiliense, Editora da Universidade de São Paulo, 1986. Para esta autora, a lógica da manutenção da ordem no Brasil Imperial supunha que os escravos seriam controlados por seus senhores, no âmbito privado; e o Estado cuidaria dos homens livres e pobres, no âmbito público.

\section{0}

Aqui caberia explorar a diferenciação entre proprietários feita por Ricardo Salles a respeito dos senhores da região de Vassouras, no século XIX: micro-proprietários (de 1 a 4 escravos), pequenos (de 5 a 19), médios (de 20 a 49), grandes (de 50 a 99) e mega-proprietários (100 ou mais). Ver SALLES, Ricardo. E o escravo era o Vale. Vassouras - século XIX. Senhores e cativos no coração do Império. Rio de Janeiro: Civilização Brasileira, no prelo.

\section{1}

Ver, principalmente MATTOS, Hebe. Das cores do silêncio - significados da liberdade no Sudeste escravista. Brasil. Século XIX. Rio de Janeiro: Arquivo Nacional, 1995.

Recebido para publicação em setembro de 2007
Interessante que, ainda seguindo estas indicações, estas pessoas - de ambos os lados das contendas - estariam, se fôssemos retomar a categoria de Maria Sylvia de Carvalho Franco, confortavelmente classificadas como "homens livres e pobres", situadas no limbo entre os cativos do eito e os grandes proprietários. Ou então, como argumentou Manuela Carneiro da Cunha, justamente por se tratar de pessoas sem posses, fora da dinâmica paternalista que ditava a relação senhor-escravo dita tradicional, ao Estado cabia a regulação de suas atividades, porque não havia quem deles se ocupasse. ${ }^{29}$

Mas não é o caso de retomar estas interpretações. Ao contrário: as ações de escravidão analisadas demonstram justamente a capacidade e as tentativas de ação regulatória do Estado, tanto no que se refere ao controle da população liberta de um modo geral, quanto a estas tentativas de reescravização por parte de senhores e às resistências de seus escravos. Estas constatações mudam completamente o sentido das questões enunciadas anteriormente. Nestes casos, um senhor sairia de sua casa para ir à Justiça reclamar seu suposto escravo porque este era, possivelmente, o bem mais valioso de que dispunha. Valia a pena, para eles, mesmo que tivessem que esperar vários anos pelo resultado. Quanto aos meios, a Justiça era, provavelmente, o único de que dispunham.

As características das pessoas envolvidas nas ações de escravidão demonstram que, sem deixar de ser senhores e escravos, eles estão no limiar de sua condição. Quase-senhores enfrentam ainda-escravos e viceversa. É desta zona de fronteira social que as ações de escravidão falam. A instabilidade da situação dos envolvidos é de tal monta que só o apelo à Justiça garantiria - mesmo assim sem certeza absoluta, já que suas situações eram reversiveis - a segurança de suas condições. ${ }^{30}$

Afinal, se em meados do século XIX, em época de aumento brutal do preço dos escravos, se era difícil para um cativo alcançar a alforria nestas circunstâncias, para o senhor de poucos escravos, a perda de um - por qualquer motivo - também era irreparável. Literalmente: seria impossível para ele conseguir comprar novamente um escravo. Estas são justamente as situações descritas nas ações de escravidão: um pequeno proprietário herda alguns escravos com a morte de seus pais; ao abrir o testamento, no entanto, descobre que sua mãe, já velha e em sinal de gratidão, libertou dois de seus três escravos. Pronto, acabou-se a herança. Na maioria das vezes, seu futuro como senhor também.

Em se tratando de forros e descendentes de africanos de maneira geral, este quadro torna-se ainda mais drástico. Perder o escravo comprado ou herdado a tanto custo significava, na prática, perder o acesso ao mundo dos livres. Muito já se analisou sobre a importância da concentração da propriedade escrava no que diz respeito ao processo de perda de legitimidade da instituição escravista na segunda metade do século XIX; 31 trata-se agora - e esta é uma questão que apenas se insinua, já no fim do texto de pensar o que a concentração do número de escravos em poucos e poderosos proprietários significa para quem a perdeu. Para estes, a discussão sobre uma carta de alforria ou sobre a legitimidade de uma doação é de extrema importância: não é só que se tratava de muito dinheiro, às vezes todos os bens de que dispunham os autores das ações de escravidão; tratava-se, fundamentalmente, de defender na Justiça sua própria condição senhorial. Sob o risco de virarem senhores sem escravos. 